\title{
Role of mTOR Signaling in Female Reproduction
}

\author{
Zaixin Guo and Qi Yu* \\ Department of Obstetrics and Gynecology, Peking Union Medical College Hospital, Peking Union Medical College and \\ Chinese Academy of Medical Sciences, Beijing, China
}

Mammalian target of rapamycin (mTOR) is a conserved serine/threonine kinase of the phosphatidylinositol kinase-related kinase family that regulates cell growth, metabolism, and autophagy. Extensive research has linked mTOR to several human diseases including cancer, neurodegenerative disorders, and aging. In this review, recent publications regarding the mechanisms underlying the role of mTOR in female reproduction under physiological and pathological conditions are summarized. Moreover, we assess whether strategies to improve or suppress mTOR expression could have therapeutic potential for reproductive diseases like premature ovarian failure, polycystic ovarian syndrome, and endometriosis.

Keywords: mTOR signaling, follicular development, oocyte maturation, ovulation, steroidogenesis, gonadotoxicity, polycystic ovarian syndrome (PCOS), endometriosis

\section{OPEN ACCESS}

Edited by:

Elke Winterhager,

University of

Duisburg-Essen, Germany

Reviewed by:

Hao Chen,

Nantong University, China

Seunghyung Lee,

Kangwon National University,

South Korea

*Correspondence:

Qi Yu

yuqi2008001@sina.com

Specialty section:

This article was submitted to

Reproduction,

a section of the journal

Frontiers in Endocrinology

Received: 18 June 2019

Accepted: 23 September 2019

Published: 09 October 2019

Citation:

Guo Z and Yu Q (2019) Role of mTOR

Signaling in Female Reproduction.

Front. Endocrinol. 10:692.

doi: 10.3389/fendo.2019.00692

\section{INTRODUCTION}

Rapamycin is a macrocyclic lactone produced by the bacterium Streptomyces hygroscopicus that was previously used as an antifungal agent but abandoned soon after because of its immunosuppressive effect $(1,2)$. The protein target of rapamycin (TOR) was originally discovered in genetic mutation studies using Saccharomyces cerevisiae (3) and subsequently found to be the target of the rapamycin-FKBP12 complex in mammalian cells, which is now referred to as the mammalian target of rapamycin (mTOR) (4-6). mTOR is sensitive to diverse environmental inputs including nutrients and growth factors, and regulates various fundamental cell processes including cell growth, metabolism, differentiation, and autophagy (7). The dysregulation of mTOR has been observed in many diseases like cancer (8), diabetes (9), neurodegenerative disorders (10), and aging (10). Further, targeting mTOR is one of the most promising fields for the efficient treatment of these diseases.

Cellular metabolism comprises the foundation of all biological activities including female reproduction $(11,12)$. Recently, accumulating lines of evidence have shown that mTOR-regulated processes are important for folliculogenesis (13), oocyte meiotic maturation (14), ovarian somatic cell proliferation and steroidogenesis (15), puberty onset (16), ovarian aging (17), endometrium changes (18), and embryonic development (19). In this review, the role of mTOR signaling in female reproduction will be discussed, and the data describing alterations to this pathway under pathological conditions will be summarized.

\section{BRIEF OVERVIEW OF mTOR SIGNALING}

mTOR forms the catalytic subunit of two different multi-molecular complexes known as mTOR complex 1 (mTORC1) and mTOR complex 2 (mTORC2) (20). mTORC1, characterized by its sensitivity to rapamycin treatment, consists of mTOR, Raptor, mLST8/GBL, PRAS40, 
and DEPTOR. mTORC2, which is insensitive to acute rapamycin treatment but is inhibited by prolonged usage (21), is composed of mTOR, Rictor, mLST8/G $\beta$ L, DEPTOR, mSin1, and protor1/2 (22).

mTORC1 plays a vital role in coordinating several cellular processes to help cells grow and divide. These processes include protein synthesis, lipid and nucleotide biogenesis, and autophagy (22). The critical effectors downstream of mTORC1 involving protein synthesis are p70S6 Kinase 1 (S6K1) and eIF4E Binding Protein 1 (4EBP1) (23), which deserve special emphasis for their important roles in female reproduction as described in the following sections. The cellular pathways upstream of mTORC1 include growth factors, stress, and amino acids (22). Briefly, numerous growth factor pathways inhibit tuberous sclerosis complex (TSC) $(24,25)$, which is composed of TSC1, TSC2, and TBC1D7 (26), relieve the inactivation of Ras homolog enriched in brain (Rheb) (27-30), and stimulate mTORC1 kinase activity. Certain incompatible stresses such as hypoxia, low ATP levels, or DNA damage, activate AMP-activated protein kinase (AMPK) pathway, which inhibits mTORC1 via the phosphorylation of Raptor (31) or TSC2 (32-34). For amino acids, there are two distinct pathways that stimulate mTORC1, and these are dependent or independent of the Rag GTPases (35-37).

The most important function of mTORC2 is the phosphorylation of Akt, which subsequently affects cell growth and proliferation (38). Moreover, mTORC2 activates several members of the AGC family, regulating cytoskeletal remodeling and cell migration (39-41). The cellular pathways upstream of mTORC2 are insulin/PI3K and mTORC1 $(42,43)$.

\section{mTOR SIGNALING IN FOLLICULOGENESIS}

During folliculogenesis, primordial follicles develop to primary, preantral, antral, and preovulatory stages, and are finally able to release an oocyte for fertilization (44-47). Primordial follicle activation, which is the beginning of follicular development after puberty, determines ovarian reserve and reproductive lifespan (44). mTOR signaling is involved in these changes. To investigate the role of mTOR signaling in this process, genetically modified mice were used in which one or several stages of different cells could be conditionally modified and specifically distinguished (Table 1). In this study, different conditional knockout (cKO) mouse models were named as follows: Gdf9-CRE-mediated cKO in primordial oocytes and all subsequent oocyte stages, referred to as "OogKO"; Zp3-CRE-mediated cKO in growing oocytes, referred to as "OozKO"; Foxl2-CRE-mediated cKO in primordial follicle granulosa cells, referred to as "pfGCKO"; AMHR2CRE-mediated cKO, referred to as "Amhr2KO"; CYP19-CREmediated cKO, referred to as "Cyp19KO." AMHR2 is mainly expressed in granulosa cells from preantral and small antral follicles, with little or no expression in the corpora luteum, large antral follicles, primordial follicles, and oocytes. Moreover, AMHR is also expressed in the fetal Müllerian duct mesenchyme and ovarian surface epithelium $(48,49)$. CYP-19 expressed in GCs of antral follicles and luteal cells (50).
mTOR signaling in oocytes is an important mechanism of primordial follicle activation, but is not necessary for the transition from primordial to primary follicle. As mentioned, TSC1 and TSC2 are negative regulators of mTORC1. A specific deletion of Tsc1 (Tsc1-OogKO) or Tsc2 (Tsc2-OogKO) genes in mouse oocytes of all stages results in the global awakening of oocytes at post-natal day (PD) 23 and depletion at 4 months of age. Enhanced mTOR signaling caused by mutation activates S6K1 signaling and promotes protein translation, leading to the overactivation of primordial follicles $(51,52)$. In particular, Tsc/mTORC1 signaling in primordial follicles is independent of PTEN (phosphatase and tensin homolog deleted on chromosome 10)/PI3K (phosphatidylinositol 3 kinase) signaling (52), despite being proposed to be a PTEN/PI3K downstream pathway in some cell types (53). Moreover, mTOR was suggested to be the functional pathway of some drugs that act on primordial follicles. Drugs such as TGF- $\beta$ R1 and AMPK inhibitors $(54,55)$ activate primordial follicles by stimulating mTOR signaling in oocytes, and LKB1 restrains primordial follicle activation by suppressing of the mTOR pathway (56). Despite facilitating the activation of primordial follicles, mTOR signaling is not indispensable for the transition from primordial follicles to primary follicles. In mTOR-OogKO female mice, more primary and fewer large secondary follicles with normal primordial follicles were shown in the ovaries at PD23. Further, the long term lack of mTOR disrupts follicular development, as it was found that there are essentially no normal follicles and many abnormal follicles that strikingly resemble testicular seminiferous tubules at 6 months of age (14). Mice with Raptor depletion in all oocytes (RaptorOogKO) were found to exhibit similar follicular development and female fertility as WT (wild-type) mice (57). Comparing mTOROogKO mouse models, only mTORC1 signaling in oocytes was found to be inhibited in Raptor-OogKO mice, and compensatory elevation of PI3K signaling was proposed to the reason for unaffected follicular development (57).

mTOR signaling in primordial follicle granulosa cells can either activate primordial follicles or impede their transition to primary follicles. Similar to Tsc1-OogKO and Tsc2-OogKO models, mice with a targeted deletion of $T s c 1$ in primordial follicle granulosa cells (Tsc1-PfGCKO) present with the premature awakening of dormant oocytes at PD23 and almost all follicles are degenerated at 4 months of age $(58,59)$. Further experiments showed that the overactivation of mTORC1 signaling in pfGCs activates KIT in oocytes through KIT ligand (KITL), which triggers a PTEN/PI3K/AKT (thymoma viral proto-oncogene 1)/FOXO3 (Forkhead box O3) cascade and awakens of dormant oocytes. As KITL is the key point of follicle activation, drugs like MAPK3/1 inhibitors could be used to preserve the ovarian reserve by inhibiting mTORC1-KITL signaling in pfGCs (60). Raptor-pfGCKO female mice display suppressed follicle activation at PD13 and PD35, and oocytes eventually die at approximately 4 months of age (59), indicating that the KIT-PI3K cascade in oocytes is indispensable for primordial follicle survival.

Suppressed mTOR signaling in the oocytes of growing follicles has relatively minor effects on the follicular development but alters the oocyte transcriptome and proteome. When mTOR is 
TABLE 1 | Ovarian-specific effects of altered mTOR signaling.

\begin{tabular}{|c|c|c|c|c|c|c|c|c|c|}
\hline Mutant mice & Tsc2-OogKO & Tsc1-OogKO & Tsc1-PfGCKO & Tsc1-Amhr2KO & Tsc1-Сур19KO & Mtor-OogKO & Mtor-OozKO & Raptor-OogKO & Raptor-pfGCKO \\
\hline Reference & Adhikari et al. (51) & Adhikari et al. (52) & Zhang et al. (59) & Tanaka et al. (49) & Huang et al. (66) & Guo et al. (14) & Guo et al. (14) & Gorre et al. (57) & Zhang et al. (59) \\
\hline mTOR signaling & Activated & Activated & Activated & Activated & Activated & Suppressed & Suppressed & Suppressed & Suppressed \\
\hline Fertility & $\begin{array}{l}\text { Infertility after } \\
12 \sim 13 \text { weeks of } \\
\text { age }\end{array}$ & $\begin{array}{l}\text { Infertility after } \\
12 \sim 13 \text { weeks of } \\
\text { age }\end{array}$ & No data & Complete infertility & 个pups/litter & $\begin{array}{l}\text { Complete infertility } \\
\text { (naturally); } \downarrow \text { rate of } \\
\text { fertilization in IVF }\end{array}$ & $\begin{array}{l}\text { Nearly complete } \\
\text { infertility (naturally); } \\
\downarrow \text { rate of fertilization } \\
\text { in IVF }\end{array}$ & Normal fertility & No data \\
\hline Estrous cycles & No data & No data & No data & $\begin{array}{l}\uparrow \text { estrous cycle } \\
\text { length, } \downarrow \text { diestrus } \\
\text { cycle length }\end{array}$ & No data & No data & No data & No data & No data \\
\hline Sex hormones & No data & $\begin{array}{l}\uparrow F S H \text { and } L H \text { at } 3 \\
\text { and } 4 \text { months }\end{array}$ & No data & $\begin{array}{l}\text { No change in E2 } \\
\text { and P4 at diestrus } \\
\text { and estrus }\end{array}$ & No data & $\begin{array}{l}\downarrow E 2 \text { and } P 4 \text { at } 6 \\
\text { months }\end{array}$ & $\begin{array}{l}\text { No change in E2 } \\
\text { and } P 4 \text { at } 6 \text { months }\end{array}$ & No data & No data \\
\hline $\begin{array}{l}\text { Follicle population } \\
\text { and health }\end{array}$ & $\begin{array}{l}\text { Follicle populations } \\
\text { normal at PD13; all } \\
\text { primordial follicles } \\
\text { activated at PD23 } \\
\text { \& PD35; almost all } \\
\text { follicles } \\
\text { degenerated at } 4 \\
\text { months }\end{array}$ & $\begin{array}{l}\text { Follicle populations } \\
\text { normal at PD5; all } \\
\text { primordial follicles } \\
\text { activated at PD23 } \\
\& 7 \text { weeks; almost } \\
\text { all follicles } \\
\text { degenerated at } 2 \\
\text { and } 3 \text { months }\end{array}$ & $\begin{array}{l}\text { Follicle populations } \\
\text { normal at PD10; all } \\
\text { primordial follicles } \\
\text { activated at PD23 } \\
\text { \& PD35; almost all } \\
\text { follicles } \\
\text { degenerated at } 4 \\
\text { months }\end{array}$ & $\begin{array}{l}\text { Follicle populations } \\
\text { normal at } 6 \text { weeks; } \\
\downarrow \text { primordial follicles } \\
\text { and } \uparrow \text { atretic follicles } \\
\text { at } 12 \text { and } 24 \\
\text { weeks; CL normal }\end{array}$ & $\begin{array}{l}\uparrow \text { growing follicles } \\
\text { and antral follicles } \\
\text { at } 6 \text { weeks; } C L \\
\text { normal at } 6 \text { weeks; } \\
\uparrow C L \text { at } 3 \text { and } 6 \\
\text { months }\end{array}$ & $\begin{array}{l}\downarrow \text { large secondary } \\
\text { and } \uparrow \text { primary } \\
\text { follicles at PD21; } \\
\downarrow \text { normal follicles at } \\
3 \text { months; no } \\
\text { normal follicles at } 6 \\
\text { months }\end{array}$ & $\begin{array}{l}\text { Follicle populations } \\
\text { normal at PD21 } \\
\text { and } 6 \text { months }\end{array}$ & $\begin{array}{l}\text { Follicle populations } \\
\text { normal at PD35 \& } \\
16 \text { weeks; CL } \\
\text { normal at } 16 \text { weeks }\end{array}$ & $\begin{array}{l}\text { Follicle populations } \\
\text { normal at PD5; } \\
\text { most follicles stay in } \\
\text { primordial follicles } \\
\text { at PD13 \& PD35; } \\
\text { no normal follicles } \\
\text { at } 4 \text { months }\end{array}$ \\
\hline $\begin{array}{l}\text { Ovulation and } \\
\text { oocyte health }\end{array}$ & No data & No data & No data & $\begin{array}{l}\text { } n \text { naturally released } \\
\text { oocytes but } 83 \% \\
\text { degenerated } \\
\text { oocytes; same } \\
\text { superovulated } \\
\text { oocytes but } 7 \text {-fold } \\
\text { increase in } \\
\text { degenerated } \\
\text { oocytes }\end{array}$ & $\begin{array}{l}\uparrow \text { naturally released } \\
\text { and superovulated } \\
\text { oocytes }\end{array}$ & $\begin{array}{l}\downarrow \text { superovulated } \\
\text { oocytes but } 78.2 \% \\
\text { oocytes display } \\
\text { incomplete } \\
\text { cytokinesis or } \\
\text { improper } \\
\text { progression of } \\
\text { meiosis to MII }\end{array}$ & $\begin{array}{l}\text { Similar } \\
\text { superovulated } \\
\text { oocytes but } 65.5 \% \\
\text { oocytes display } \\
\text { incomplete } \\
\text { cytokinesis or } \\
\text { improper } \\
\text { progression of } \\
\text { meiosis to MII }\end{array}$ & No data & No data \\
\hline $\begin{array}{l}\text { Embryo } \\
\text { development }\end{array}$ & No data & No data & No data & $\begin{array}{l}\uparrow E 2.5 \text { embryos but } \\
2 / 3 \text { degenerated } \\
\text { bodies; E3.5 } \\
\text { embryos stay in } \\
\text { ampullas }\end{array}$ & No data & $\begin{array}{l}\downarrow \text { progression to } \\
2 \text {-cell and } \\
\text { blastocyst stage in } \\
\text { IVF }\end{array}$ & $\begin{array}{l}\downarrow \text { progression to } \\
2 \text {-cell and } \\
\text { blastocyst stage in } \\
\text { IVF }\end{array}$ & No data & No data \\
\hline
\end{tabular}


specifically knocked out in growing follicles (mTOR-OozKO), follicular development and the ovulation rate are virtually the same as those in WT mice. However, the oocyte meiotic progression and developmental competence of released oocytes is impaired (14). To explain the impairment, the transcriptome of fully grown GV (germinal vesicle) oocytes and the proteome of ovulated oocytes was tested. Here, 85 transcripts and 237 proteins were found to be differentially expressed in Mtor-ZcKO oocytes. Particularly, down-regulated proteins were involved in the processes "mRNA metabolic process" and "actin filament bundle assembly" (14). At the completion of oocyte growth, transcription is actively silenced and protein translation slows substantially such that selective proteins are stored during oocyte growth (61). Thus, these defects, after ovulation, reflect the differences during folliculogenesis, although follicular growth appears to be the same between mTOR-OozKO and WT mice.

Activation of mTOR signaling in granulosa cells promotes follicular development as FSH-stimulated differentiation of GCs is necessary for follicular growth $(62,63)$. In GCs in vitro, activity of hypoxia-inducible factor- $1 \alpha$ (HIF-1 $\alpha$ ) stimulated by FSH is mediated by mTOR signaling, and HIF- $1 \alpha$ is necessary for FSH-enhanced induction of multiple follicular differentiation markers and facilitates follicular differentiation to a preovulatory phenotype $(64,65)$. There are two mutant mice with stimulated mTOR signaling at different stages of GCs, presenting with distinct effects on follicular growth. Tsc1- Cyp19KO mice have more growing follicles in the ovary, more released oocytes, and give birth to more pups than control animals (66), indicating the catalytic role of elevated mTOR signaling. However, Tsc1Amhr2KO mice have fewer primordial follicles but more atretic follicles in the ovary, as well as a similar number of healthy but more degenerated ovulated oocytes. The number of good-quality embryos was found to be the same as that in WT animals after natural mating which was determined by puncturing ampullas as the oviducts of Tsc1-Amhr2KO mice are blocked (49). As $\mathrm{AMH}$ is only expressed in granulosa cells from preantral and small antral follicles, it was speculated that increased mTOR signaling promotes enhanced follicular growth but many of these are finally atretic without sufficient mTOR in large antral follicles. Moreover, unhealthy oocytes is probably from previous ovulation accumulated in the blocked oviducts as healthy oocytes and embryos were the same as those in WT mice (49). However, these contentions require more experimental evidence.

\section{mTOR SIGNALING DURING OOCYTE MEIOTIC MATURATION}

Immature oocytes maintain meiotic arrest until stimulation, which could comprise LH in mammals or progesterone/insulin/IGF-1 in frogs, and then resume the meiotic cell cycle. The following events include nuclear envelope breakdown (NEBD), chromatin condensation, first meiotic spindle formation (metaphase I, MI), and the first polar body extrusion (metaphase II, MII) $(67,68)$. During these processes, the localization of mTOR changes with time. mTOR is observed in the cytoplasm at the GV stage, around the chromosomes at NEBD, and on the spindle during MI-MII stages (69). To distinguish mTORC1 and mTORC2, raptor and rictor are also localized separately. Raptor co-localizes with mTOR on the spindle but rictor is expressed on the spindle poles of MI oocytes (69), indicating that mTORC1 and mTORC2 have different contributions to meiotic division.

Oocyte meiotic maturation encompasses the activation of translation and increases in overall protein synthesis, which has a close relationship with mTORC1 signaling. mTORC1 takes part in protein synthesis relying on S6K1 and 4EBP1. S6K1 relays the signal comprising the decision of whether to prepare for mRNA translation (70). 4EBP1 contributes to overall cap-dependent translation. Specifically, formation of the cap-binding protein complex is inhibited when hypophosphorylated 4EBP1 binds eIF4E (70). Although both signals are downstream of mTORC1, they exhibit divergent expression with respect to species variation. Moreover, rapamycin also displays different effects. In Rana dybowskii oocytes, S6K1 activity increases after progesterone stimulation and rapamycin blocks progesterone-induced oocyte GVBD in a dose-dependent manner (71). In Xenopus, although S6K1 and 4EBP1 are stimulated by progesterone or insulin, oocyte meiotic maturation and the activation of overall protein synthesis are unaffected by rapamycin $(72,73)$. This phenomenon could be explained by the effect of Xenopus oocytes' cap-independent translation mechanism (74), but whether rapamycin has other effects on oocytes has not been explored. In mammalian oocytes, 4EBP1 becomes gradually phosphorylated during meiotic maturation, which was shown in bovine, porcine, and murine models (7577). S6K1 is already highly phosphorylated at the GV stage and significantly decreases in murine oocytes $(76,78)$, which occurs to conserve energy for costly cell cycle processes (79). In mouse oocytes, mTOR-4EBP1-eIF4E inhibitors including rapamycin and eIF4E antibodies do not block meiotic progression, but lead to abnormalities in spindle morphology and chromosome alignment, in turn resulting in chromosomal aneuploidy (78). This indicates that the disruption of mTOR signaling only downregulates the translation of specific mRNAs involved in spindle assembly and chromosomal alignment but does not influence overall translations (78). Other mechanism could explain other translation-associated effects (80).

Moreover, the actin cytoskeleton mediates various vital functions during oocyte meiotic maturation $(81,82)$, which is related to mTORC2 signaling (39). mTORC2 functions upstream of Rho GTPases to regulate the actin cytoskeleton (39), which participates in various events during meiotic maturation (81). Upon disrupting both mTORC1 and mTORC2 with prolonged rapamycin treatment or an mTOR antibody in mouse oocytes, spindle migration and asymmetric division are inhibited (83), which was found to be actin-dependent $(81,82)$.

\section{mTOR SIGNALING IN OVARIAN SOMATIC CELLS}

The expression of mTOR and associated signaling components in granulosa cells (GCs), theca-interstitial cells (TICs), and 
luteal cells is well-documented. These cells respond to many factors to proliferate and produce steroid hormones. Of these factors, gonadotropins such as follicle stimulate hormone (FSH), luteinizing hormone (LH), and human chorionic gonadotropin (hCG) have the most important role.

mTOR signaling regulates GC proliferation in response to FSH stimulation and TIC proliferation stimulated by LH/hCG. As the mTOR pathway regulates meiotic processes, meiosis is also modulated by mTOR based on its effects on cell cycle regulatory protein synthesis (84). Under in vitro FSH stimulation, rat GCs increased and mTOR signaling is enhanced in a dosedependent manner (85). Further, proliferation can be improved by increasing of cyclin D2 mRNA expression, which regulates the progression of the cell cycle (86). Rapamycin was found to suppress these process significantly (85). Further studies proved that FSH uses a cAMP/PKA (protein kinase A)/ERKdependent pathway to stimulate mTOR signaling (85). It is worth mentioning that immortalized rat GCs are arrested in the G1 cell cycle stage by applying rapamycin, which also reveals mTOR functions in the cell cycle $(87,88)$. The proliferation of rat TICs in vitro is stimulated by LH/hCG and is mTOR-dependent, which was shown based on the expression of proliferative markers like CDK4, cyclin D3, and PCNA. In contrast to GCs, the proliferation of TICs occurs via the cAMP/PI3K/AKT cascade, and not the PKA/ERK pathway (89). Similarly, insulin also stimulates TIC proliferation via activation of the mTOR pathway (90).

mTOR signaling also participates in steroidogenesis. In TICs, the inhibition of mTORC1 by rapamycin $(20 \mathrm{nM})$ was found to reduce the expression Cyp11a1, Hsd3b1, and Cyp17a1 mRNA and the production of androstenedione in response to hCG. CREB (cAMP response element-binding protein) acts as downstream of S6K1 and mediates changes in gene expression in response to gonadotropin $(15,91)$. In human granulosa lutein cells, pretreatment with rapamycin $(20 \mathrm{nM})$ inhibits the hCG-induced upregulation of Cyp11a1, Hsd3b1, and Star mRNA and the production of progesterone in vitro (92). However, in bovine luteal cells, despite being activated by LH, mTOR signaling does not contribute to corpus luteum (CL)-derived progesterone synthesis (93).

Although mTOR signaling is speculated to be involved in luteal cell autophagy, further experiments disproved this. CL regression occurs if fertilization does not occur, and an important mechanism underlying the function of the CL is luteal cell autophagy (94). Although mTOR signaling is presumed to play a part in CL regression and stimulating the response to PGF2 $\alpha$ (95), an important mediator of CL regression through increased ERK1/2 activity (96), another study suggested that luteal cell autophagy is induced by enhanced ERK1/2 activity and is independent of mTOR activity (97).

\section{MTOR SIGNALING IN PUBERTY ONSET, FERTILITY, AND OVARIAN AGING}

mTOR signaling is highly expressed in the hypothalamus (98), and affects puberty onset when it is suppressed. After blocking central mTOR signaling via the intracerebroventricular administration of rapamycin in rats, puberty onset was found to be inhibited, which presented as decreased LH and estradiol levels, delayed vaginal opening, and atrophied ovaries and uterus (16). As mTOR signaling stimulates protein synthesis and inhibits autophagy in the presence of nutrients (98), hypothalamic mTOR signaling was proposed to play a part in the metabolic regulation of female puberty. The mechanism underlying the role of mTOR in puberty onset was implied by the fact that rapamycin suppresses arcuate nucleus (ARC) Kiss1 levels (16), the upstream regulator of $\mathrm{GnRH}$ release, which controls puberty onset (99). Interestingly, mTOR signaling seems to regulate Kiss1 neurons indirectly, as pS6 (the downstream of mTOR and S6K1) is not expressed in Kiss1 neurons (100). However, AMP-activated protein kinase (AMPK), another energy sensor activated by conditions of energy insufficiency (101), appears to be expressed in Kiss1 neurons, and has a putative role in the interplay between mTOR signaling and puberty onset (102). Although the significant effects of rapamycin on puberty onset were determined in animal experiments, patients clinically treated with rapamycin before menarche were found to have a similar menarche time as patients administered rapamycin postmenarche (103). The difference could be explained by the fact that rapamycin administered orally has little effects on mTOR signaling in the brain (104), although rapamycin is believed to cross the blood-brain barrier (105), and reduce depression and anxiety $(106,107)$.

Rapamycin disrupts menstruation and ovulation, leading to infertility both in animals and humans. As mentioned, mTOR signaling is indispensable for follicular development and the effects of rapamycin on fertility are easily demonstrated. Rapamycin impedes ovulation and affects menstruation in vivo. Mice exhibit irregular estrous cycles when administered rapamycin $(5 \mathrm{mg} / \mathrm{kg}$ every other day or $2 \mathrm{mg} / \mathrm{kg}$ every day, i.p.) $(17,108)$. Serum analysis also revealed that progesterone (P4) is decreased dramatically (108). Further, ovarian morphological assessments demonstrated an increased number of primordial follicles and a decreased number of all growing follicles and the CL. During a superovulation regiment, the injection of rapamycin (5 or $50 \mathrm{mg} / \mathrm{kg}$ body weight for 4 days, i.p.) led to a dose-dependent decrease in the numbers of eggs released (88). Moreover, rapamycin-treated mice had no pregnancies during the mating trial (17). In the clinic, patients administered rapamycin present with similar phenomena. Rapamycin increases the risk of oligomenorrhea and/or ovarian cysts in patients with tuberous sclerosis complex (103), transplantation (109), and autosomal dominant polycystic kidney disease (110). In addition, the percentage of patients who experienced at least one menstrual irregularity was determined to be as high as $38.4 \%$ in the tuberous sclerosis complex study with 112 patients (103). Interestingly, all disturbances in menstruation returned to normal 2 months after stopping treatment (108), indicating that the function of rapamycin does not persist.

The inhibition of mTOR signaling can also prolong ovarian lifespan. Compared to that in control rats, rapamycin-treated rats have a 2 -fold increase in the number of primordial follicles after 10 weeks of treatment with rapamycin $(5 \mathrm{mg} / \mathrm{kg}$ every other day, 
i.p.) $(17,111)$. These results indicate that rapamycin can protect the ovarian reserve and extend ovarian lifespan. An interesting experiment also showed that a transient 2-weeks regimen of rapamycin facilitates the sufficient extension of ovarian lifespan in mice regardless of the age at treatment initiation (108). Although improvements in oocyte quality and the ovarian microenvironment were demonstrated experimentally, this requires more exploration to identify the relationship between treatment time and the extension of ovarian lifespan.

\section{mTOR SIGNALING IN THE ENDOMETRIUM}

The endometrium undergoes cyclical and rhythmic changes under the influence of complex autocrine, paracrine and endocrine signaling (112). Further, this is a process involving cell proliferation, differentiation, apoptosis, autophagy, and decidualization, in which mTOR signaling plays a role. Estradiol$17 \beta$ (E2) and P4 are the most important factors orchestrating cell division and differentiation of the endometrium. E2 regulates protein synthesis and DNA synthesis in uterine epithelial cells through the PKC (phospho-kinase C)/ERK/mTOR pathway, which finally manipulates cell proliferation. However, P4 inhibits only the E2-induced DNA synthetic response without affecting mTOR signaling, indicating another pathway responsible for P4 inhibition (18). The suppression of mTOR signaling also promotes human endometrial stromal cell (ESC) apoptosis via autophagy induction, which is mediated by $\mathrm{S} 6 \mathrm{~K} 1$ and can be determined based on LC3-II expression (113, 114). Decidualization, the transformation of endometrial stromal cells into specialized secretory decidual cells (115), is affected by $\mathrm{nm} 23$ via the PI3K-Akt-mTOR signaling pathways in mouse ESCs and human ESCs (116). Based on the vital roles of mTOR in modulating the endometrium, its influence on endometrial receptivity, which renders the endometrium suitable for embryo development $(117,118)$, is easily understood. Experiments have shown that activation of the ERK1/2-mTOR pathway is one mechanism through which fludrocortisone affects uterine receptivity in mice (119).

In addition, the mTOR pathway also participates in implantation. Levels of mTOR in the pregnant mice are higher than those in non-pregnant mice. Moreover, the levels are increased from $\mathrm{PD} 3$, reach a maximum on PD5, and then decline thereafter (120). Stimulation of the $\mathrm{PI} 3 \mathrm{~K} / \mathrm{PKB} / \mathrm{mTOR} / \mathrm{NO}$ signaling pathway by dietary arginine supplementation can also enhance embryo implantation (121). mTOR is also indispensable for placentation in the porcine uterine tissue based on its important function during translation $(122,123)$.

\section{mTOR SIGNALING DURING POST-FERTILIZATION EVENTS}

mTOR signaling is essential for embryonic development both in vivo and in vitro. In Drosophila melanogaster, cell size and embryonic lethality are reduced when TOR or S6 kinase is silenced $(124,125)$. In mice, disruption of mTOR completely results in the death of embryos shortly after implantation, which was attributed to impaired cell proliferation in both embryonic and extraembryonic compartments. This was proven by in vitro experiments in which both the inner cell mass (ICM) and trophoblasts fail to proliferate in mTOR-deleted mouse blastocysts (19). When mTOR is disrupted partly, mutant embryos die at midgestation coitum, which is accompanied by failed telencephalon cell growth and rotation around the embryonic body axis $(126,127)$. Different from that with mTOR, mice deficient in S6K1 are viable and smaller in body size, which could be explained by the fact that S6K1 only represents one part of mTOR signaling (128). Drugs that inhibit mTOR signaling impair blastocysts growth, but the effects are reversible. When treated with rapamycin $(200 \mathrm{nM})$, growth of the ICM is not inhibited, but trophoblast outgrowth of blastocysts is impeded (19). Interestingly, the proliferation of embryonic stem cells is also refractory to rapamycin. An insufficient number of rapamycin receptors or the existence of mTORC2 could be the reason for this (19). Another exciting discovery is that the inhibition of both mTORC1 and mTORC2 complexes using INK128 or RapaLink-1 results in a diapause state of blastocysts. Diapause is a reversible pausing state triggered by unfavorable conditions $(129,130)$. When the inhibition is relieved, blastocysts can give rise to live, fertile mice (131).

mTOR signaling also takes part in mammalian embryonic differentiation, during which embryonic stem cells and pluripotent stem cells grow into the endoderm, ectoderm and mesoderm (132). Interestingly, mTOR signaling presents different functions in mouse embryonic stem cells and human pluripotent stem cells. In mice, the activation mTOR induces mouse embryonic stem cell differentiation. Increasing mTOR activity via withdrawal of the cytokine leukemia inhibitory factor from mouse embryonic stem cell culture can induce mouse embryonic stem cell differentiation $(133,134)$. Further, a decrease in mTORC2 activity, resulting from the knockdown of calcineurin, impairs mesoderm differentiation (135). In contrast to that in mouse embryonic stem cells, mTOR inhibition promotes human pluripotent stem cell differentiation. The knockdown of Raptor in human pluripotent stem cells induces mesendoderm differentiation (136), and the same effect occurs when treating human pluripotent stem cells with rapamycin (137). The mechanism underlying this difference between mice and humans is not understood, and additional studies are needed to explore this, as the cell populations are similar (138).

\section{ROLES OF MTOR SIGNALING IN FEMALE REPRODUCTIVE PATHOLOGY}

As mTOR signaling affects many processes associated with reproduction, manipulating this pathway to preserve fertility has been explored in preclinical studies. The pharmacologic downregulation of mTOR protects the ovarian reserve in the presence of ovarian toxic drugs in animal models (139), as mTOR is related to primordial follicle activation. In fact, anticancer therapies such as genotoxic or antimitotic agents hardly impair most oocytes in primordial follicles. However, when the ovary is repeatedly exposed to chemotherapy, primordial follicles are 
activated and grow to replace damaged growing follicles (140, 141). Thus, regimens to counteract follicle activation could prevent premature ovarian failure induced by toxicity. It was also confirmed that mTOR inhibitors can promote follicular quiescence and prevent premature ovarian failure when used in cyclophosphamide-induced and cisplatin-induced ovarian dysfunctional animal models $(139,142,143)$.

Activating mTOR signaling is a vital mechanism used in primordial follicle growth activation (PFGA) (144), which has great potential to assist reproduction. PFGA is an explored technology that is expected to provide benefits for patients with diminished ovarian reserve or malignant tumors. One problem with hormonal stimulation strategies used clinically is that they cannot fully utilize most follicles remaining in the ovary such as primordial follicles but largely rely on the population of growing follicles. Thus, a critical step to fully exploit the ovarian follicle is to overcome the mechanism resulting in the growth-arrest of primordial follicles (144). mTOR activators (phosphatidic acid, propranolol) can induce the awakening of primordial follicles in the human ovarian cortex such that more mature follicles

TABLE 2 | Role of mTOR signaling in female reproductive cells and organs.

\begin{tabular}{|c|c|c|c|c|}
\hline Cell type & Proposed function & Species & Proposed mediator & References \\
\hline \multirow[t]{3}{*}{ Oocyte } & Folliculogenesis & Mouse & No data. & $(14,49,51,52,57)$ \\
\hline & Maturation & Mouse, porcine, bovine & elF4E, Rho GTPases & $(39,75-78,83)$ \\
\hline & Ovarian aging & Mouse & No data. & $(17,111)$ \\
\hline \multirow[t]{2}{*}{ Granulosa cells } & Folliculogenesis & Rat, mouse & $\mathrm{HIF}-1 \alpha$ & $(49,64-66)$ \\
\hline & FSH induced-proliferation & Rat & Cyclin D & $(85,86)$ \\
\hline \multirow[t]{2}{*}{ Luteal granulosa cells } & Steroidogenesis & Human; not applicable for bovine & Cyp11a1, Hsd3b1, Star & $(92,93)$ \\
\hline & Autophagy (proven to unrelated) & Rats & - & $(95,97)$ \\
\hline Primordial follicle granulosa cells & Folliculogenesis & Mouse & KITL & (59) \\
\hline \multirow[t]{2}{*}{ Theca-interstitial cells } & LH/hCG induced proliferation & Rat & CDK4, Cyclin D, PCNA & (89) \\
\hline & Steroidogenesis & Rat & CREB, Cyp11a1, Hsd3b1, Cyp17a1 & (15) \\
\hline Hypothalamus & Puberty onset & Mouse & Kiss 1 & $(16)$ \\
\hline \multirow[t]{2}{*}{ Embryo } & Embryo development & Mouse & No data & $(19,128-131)$ \\
\hline & Embryo differentiation & Mouse, human & No data & $(133-138)$ \\
\hline \multirow[t]{3}{*}{ Endometrium } & Proliferation; apoptosis; autophagy & Mouse, human & No data & $(18,112-116)$ \\
\hline & Implantation & Mouse & $\mathrm{NO}$ & $(120,121)$ \\
\hline & Placentation & Porcine & No data & $(122,123)$ \\
\hline
\end{tabular}

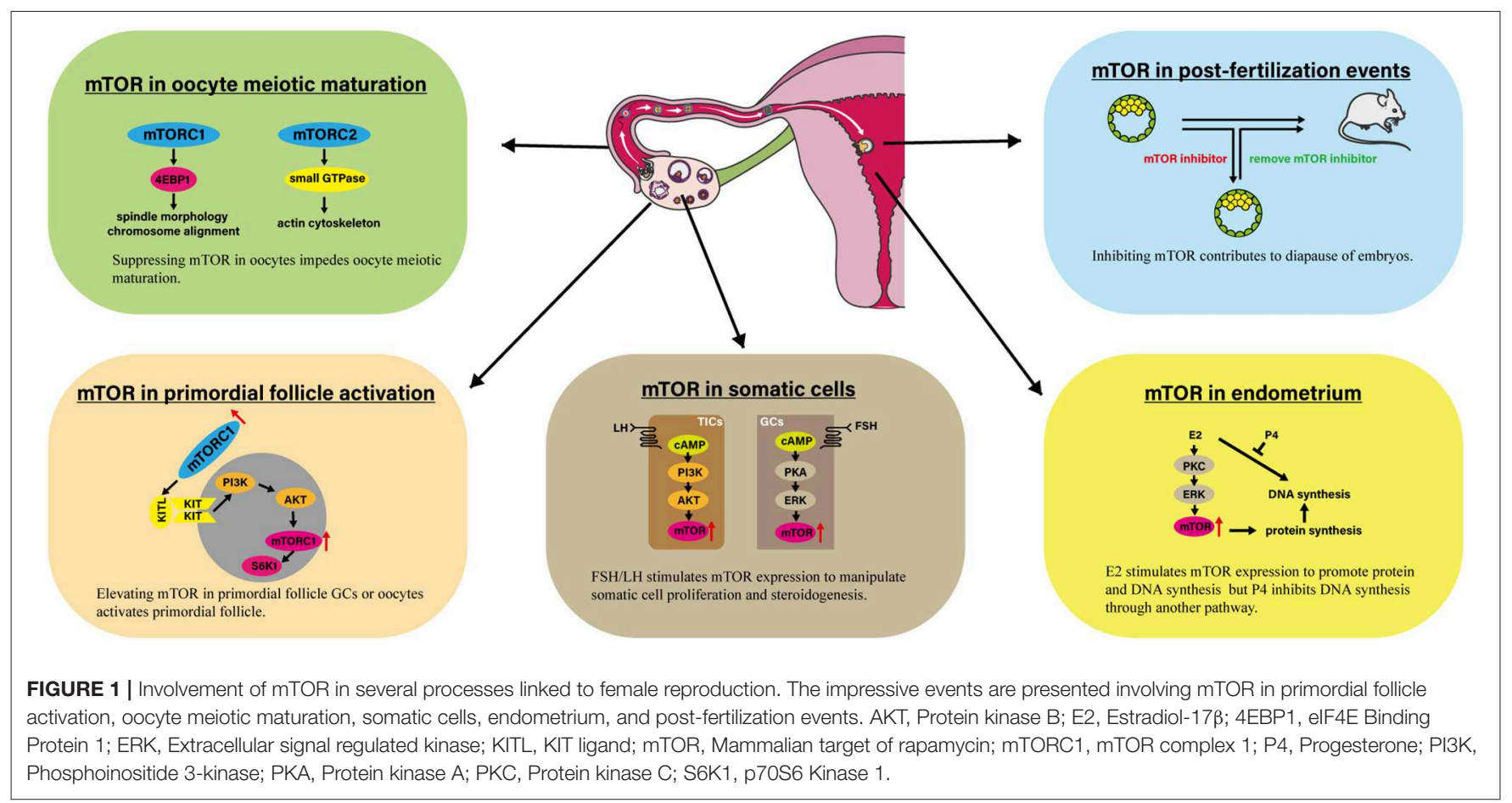


can be obtained in combination with other primordial follicle activators $(145,146)$.

Polycystic ovarian syndrome (PCOS) is a multifactorial endocrinopathy that affects reproduction and metabolism (147, 148). Many conclusions involving the relationship between PCOS and mTOR signaling are paradoxical and complex. For example, in a DHEA-induced PCOS mouse model, the expression of mTOR and p-mTOR (serine-2448) in the ovary was found to be higher than that in normal mice, but S6K1 is decreased in the DHEA-treated PCOS mouse ovary. With respect to this, the authors speculated that insufficient S6K1 activation causes an arrest in follicular development but they could not explain the discrepancy in expression between mTOR and downstream signaling (149). In another study, mTOR protein levels in luteal GCs of PCOS patients were the same as those in healthy women. However, less mTOR protein expression is observed in luteal GCs with PCOS compared to that in healthy patients upon stimulation with insulin (150). Therefore, further experiments are needed to delineate the accurate expression of mTOR in PCOS. Another characteristic linking PCOS and mTOR is metabolic disorder during PCOS. Rapamycin was found to enhance insulin sensitivity and improve serum lipid profiles after long term treatment (151). Thus, rapamycin is expected to be used to eliminate metabolic syndrome with PCOS despite potential adverse effects on fertility and short-term metabolism.

Endometriosis, a gynecological disease caused by the dislocation of endometrial cells, is characterized by inflammation and to progesterone resistance (152). Inadequate responses to progesterone in eutopic and ectopic endometrial cells and tissue contribute to increased cell proliferation (153), in which mTOR is involved. The ectopic endometrium of patients with endometriosis exhibits increased phosphorylation of mTOR compared to that in the eutopic endometrium (154-156). Moreover, the inhibition of mTOR can suppress endometriotic foci in a rat/mouse model of endometriosis $(157,158)$ and promote human endometriotic cell apoptosis via autophagy induction $(113,159)$. In addition to the ectopic endometrium, aberrant decidualization in the eutopic endometrium of women with endometriosis impairs implantation partially through the activation of PI3K/AKT $(160,161)$. As mTORC2 is downstream of AKT, it can be postulated that mTOR is activated in the eutopic endometrium, but this requires experiments for confirmation.

\section{CONCLUSIONS}

mTOR signaling plays a vital role in regulating female reproduction, which has been demonstrated based on data from

\section{REFERENCES}

1. Sehgal SN, Baker H, Vezina C. Rapamycin (AY-22,989), a new antifungal antibiotic. II. Fermentation, isolation and characterization. J. Antibiotics. (1975) 28:727-32. doi: 10.7164/antibiotics. 28.727 genetic, pharmacological, and clinical studies (Table 2, Figure 1). mTOR signaling participates in various process that occur in the ovary, including ovarian reserve, follicle development, oocyte meiotic maturation, ovarian aging, and proliferation and steroidogenesis of ovarian somatic cells, among others. There are two impressive functions of mTOR signaling in the ovary. First, elevated mTOR expression in both oocytes and primordial follicle GCs activates the primordial follicle, which has great potential for applications of ovarian reserve protection and PFGA. Second, suppressing mTOR hinders oocyte meiotic maturation, which could limit the use of mTOR-suppressing drugs for fertilityrelated diseases. In addition to that in the ovary, mTOR appears to be crucial for hypothalamus functions, endometrium changes, and embryo development. Finally, preclinical evidence suggests the possibility of applying mTOR modulators to ameliorate fertility issues associated with POF, PCOS, and endometriosis.

Although rapamycin and catalytic mTOR inhibitors are already successfully used to prevent the rejection of transplants or treat some types of cancer, many studies are needed to translate experimental results to clinical use for female reproductive diseases. On one hand, mTOR seems to be much more than a simple positive or negative trigger of female reproduction. Under physiological conditions, mTOR is regulated by different factors in a joint effort to determine the outcome of several processes including folliculogenesis, ovulation, endometrium changes, or embryonic development. On the other hand, the complete inhibition of mTOR would cause severe dose-limiting toxicities based on the indispensable role of mTOR in most human tissues. Thus, it has yet to be determined if it is worthwhile to cure non-life threatening diseases with an mTOR inhibitor $(162,163)$. Future work should focus on the development of tissue-specific therapeutics to avoid drawbacks associated with effects on unrelated tissues. Overall, mTOR clearly plays an important role in female reproduction. However, much work is needed to fully understand the mechanisms underlying the role of mTOR in female reproduction and to completely unlock the therapeutic potential of this signaling pathway.

\section{AUTHOR CONTRIBUTIONS}

ZG collected the information, designed the figures, wrote the manuscript, and submitted the manuscript. QY contributed to manuscript conception, design, and critical discussion.

\section{FUNDING}

This work was supported by CAMS Innovation Fund for Medical Sciences (CIFMS) (2017-I2m-2-002), China. rapamycin (mTOR) for health and diseases. Drug Discov Today. (2007) 12:112-24. doi: 10.1016/j.drudis.2006.12.008

3. Heitman J, Movva NR, Hall MN. Targets for cell cycle arrest by the immunosuppressant rapamycin in yeast. Science. (1991) 253:9059. doi: $10.1126 /$ science. 1715094 
4. Brown EJ, Albers MW, Shin TB, Ichikawa K, Keith CT, Lane WS, et al. A mammalian protein targeted by G1-arresting rapamycin-receptor complex. Nature. (1994) 369:756-8. doi: 10.1038/369756a0

5. Sabatini DM, Erdjument-Bromage H, Lui M, Tempst P, Snyder SH. RAFT1: a mammalian protein that binds to FKBP12 in a rapamycindependent fashion and is homologous to yeast TORs. Cell. (1994) 78:3543. doi: 10.1016/0092-8674(94)90570-3

6. Cafferkey R, Young PR, McLaughlin MM, Bergsma DJ, Koltin Y, Sathe GM, et al. Dominant missense mutations in a novel yeast protein related to mammalian phosphatidylinositol 3-kinase and VPS34 abrogate rapamycin cytotoxicity. Mol Cell Biol. (1993) 13:6012-23. doi: 10.1128/MCB.13.10.6012

7. Long X, Muller F, Avruch J. TOR action in mammalian cells and in Caenorhabditis elegans. Curr Topics Microbiol Immunol. (2004) 279:11538. doi: 10.1007/978-3-642-18930-2_8

8. Moschetta M, Reale A, Marasco C, Vacca A, Carratu MR. Therapeutic targeting of the mTOR-signalling pathway in cancer: benefits and limitations. Br J Pharmacol. (2014) 171:3801-13. doi: 10.1111/bph.12749

9. Ardestani A, Lupse B, Kido Y, Leibowitz G, Maedler K. mTORC1 signaling: a double-edged sword in diabetic $\beta$ cells. Cell Metab. (2018) 27:31431. doi: 10.1016/j.cmet.2017.11.004

10. Perluigi M, Di Domenico F, Butterfield DA. mTOR signaling in aging and neurodegeneration: At the crossroad between metabolism dysfunction and impairment of autophagy. Neurobiol Dis. (2015) 84:3949. doi: 10.1016/j.nbd.2015.03.014

11. Zhu J, Thompson CB. Metabolic regulation of cell growth and proliferation. Nat Rev Mol Cell Biol. (2019) 20:436-50. doi: 10.1038/s41580-0190123-5

12. Seli E, Babayev E, Collins SC, Nemeth G, Horvath TL. Minireview: metabolism of female reproduction: regulatory mechanisms and clinical implications. Mol Endocrinol. (2014) 28:790-804. doi: 10.1210/me.2013-1413

13. Herta AC, Lolicato F, Smitz JEJ. In vitro follicle culture in the context of IVF. Reproduction. (2018) 156: F59-73. doi: 10.1530/REP-18-0173

14. Guo J, Zhang T, Guo Y, Sun T, Li H, Zhang X, et al. Oocyte stage-specific effects of MTOR determine granulosa cell fate and oocyte quality in mice. Proc Natl Acad Sci USA. (2018) 115: E5326-33. doi: 10.1073/pnas.1800352115

15. Palaniappan $\mathrm{M}$, Menon KM. Luteinizing hormone/human chorionic gonadotropin-mediated activation of mTORC1 signaling is required for androgen synthesis by theca-interstitial cells. Mol Endocrinol. (2012) 26:1732-42. doi: 10.1210/me.2012-1106

16. Roa J, Garcia-Galiano D, Varela L, Sánchez-Garrido MA, Pineda R, Castellano JM, et al. The mammalian target of rapamycin as novel central regulator of puberty onset via modulation of hypothalamic kiss1 system. Endocrinology. (2009) 150:5016-26. doi: 10.1210/en.2009-0096

17. Zhang XM, Li L, Xu JJ, Wang N, Liu WJ, Lin XH, et al. Rapamycin preserves the follicle pool reserve and prolongs the ovarian lifespan of female rats via modulating mTOR activation and sirtuin expression. Gene. (2013) 523:82-7. doi: 10.1016/j.gene.2013.03.039

18. Wang Y, Zhu L, Kuokkanen S, Pollard JW. Activation of protein synthesis in mouse uterine epithelial cells by estradiol-17beta is mediated by a PKCERK1/2-mTOR signaling pathway. Proc Natl Acad Sci USA. (2015) 112: E1382-91. doi: 10.1073/pnas.1418973112

19. Murakami M, Ichisaka T, Maeda M, Oshiro N, Hara K, Edenhofer F, et al. mTOR is essential for growth and proliferation in early mouse embryos and embryonic stem cells. Mol Cell Biol. (2004) 24:67108. doi: 10.1128/MCB.24.15.6710-6718.2004

20. Loewith R, Jacinto E, Wullschleger S, Lorberg A, Crespo JL, Bonenfant $D$, et al. Two TOR complexes, only one of which is rapamycin sensitive, have distinct roles in cell growth control. Mol Cell. (2002) 10:45768. doi: 10.1016/S1097-2765(02)00636-6

21. Lamming DW, Ye L, Katajisto P, Goncalves MD, Saitoh M, Stevens $\mathrm{DM}$, et al. Rapamycin-induced insulin resistance is mediated by mTORC2 loss and uncoupled from longevity. Science. (2012) 335:1638-43. doi: 10.1126/science.1215135

22. Saxton RA, Sabatini DM. mTOR signaling in growth, metabolism, and disease. Cell. (2017) 168:960-76. doi: 10.1016/j.cell.2017.02.004
23. Nojima H, Tokunaga C, Eguchi S, Oshiro N, Hidayat S, Yoshino K, et al. The mammalian target of rapamycin (mTOR) partner, raptor, binds the mTOR substrates p70 S6 kinase and 4E-BP1 through their TOR signaling (TOS) motif. J Biol Chem. (2003) 278:15461-4. doi: 10.1074/jbc.C200665200

24. Benvenuto G, Li S, Brown SJ, Braverman R, Vass WC, Cheadle JP, et al. The tuberous sclerosis-1 (TSC1) gene product hamartin suppresses cell growth and augments the expression of the TSC2 product tuberin by inhibiting its ubiquitination. Oncogene. (2000) 19:6306-16. doi: 10.1038/sj.onc.1204009

25. Tee AR, Fingar DC, Manning BD, Kwiatkowski DJ, Cantely LC, Blenis J. Tuberous sclerosis complex-1 and -2 gene products function together to inhibit mammalian target of rapamycin (mTOR)-mediated downstream signaling. Proc Natl Acad Sci USA. (2002) 99:135716. doi: 10.1073/pnas.202476899

26. Dibble CC, Elis W, Menon S, Qin W, Klekota J, Asara JM, et al. TBC1D7 is a third subunit of the TSC1-TSC2 complex upstream of mTORC1. Mol Cell. (2012) 47:535-46. doi: 10.1016/j.molcel.2012.06.009

27. Garami A, Zwartkruis FJ, Nobukuni T, Joaquin M, Roccio M, Stocker $\mathrm{H}$, et al. Insulin activation of Rheb, a mediator of mTOR/S6K/4EBP signaling, is inhibited by TSC1 and 2. Mol Cell. (2003) 11:145766. doi: 10.1016/S1097-2765(03)00220-X

28. Inoki $\mathrm{K}$, $\mathrm{Li} \mathrm{Y}, \mathrm{Xu} \mathrm{T}$, Guan KL. Rheb GTPase is a direct target of TSC2 GAP activity and regulates mTOR signaling. Genes Dev. (2003) 17:182934. doi: $10.1101 /$ gad.1110003

29. Stocker H, Radimerski T, Schindelholz B, Wittwer F, Belawat P, Daram P, et al. Rheb is an essential regulator of $\mathrm{S} 6 \mathrm{~K}$ in controlling cell growth in Drosophila. Nat Cell Biol. (2003) 5:559-65. doi: 10.1038/ncb995

30. Zhang Y, Gao X, Saucedo LJ, Ru B, Edgar BA, Pan D. Rheb is a direct target of the tuberous sclerosis tumour suppressor proteins. Nat Cell Biol. (2003) 5:578-81. doi: 10.1038/ncb999

31. Gwinn DM, Shackelford DB, Egan DF, Mihaylova MM, Mery A, Vasquez DS, et al. AMPK phosphorylation of raptor mediates a metabolic checkpoint. Mol Cell. (2008) 30:214-26. doi: 10.1016/j.molcel.2008.03.003

32. Shah OJ, Wang $Z$, Hunter $T$. Inappropriate activation of the TSC/Rheb/mTOR/S6K cassette induces IRS1/2 depletion, insulin resistance, and cell survival deficiencies. Curr Biol. (2004) 14:1650-6. doi: 10.1016/j.cub.2004.08.026

33. Inoki $\mathrm{K}$, Zhu $\mathrm{T}$, Guan $\mathrm{KL}$. TSC2 mediates cellular energy response to control cell growth and survival. Cell. (2003) 115:577-90. doi: 10.1016/S0092-8674(03)00929-2

34. Plescher M, Teleman AA, Demetriades C. TSC2 mediates hyperosmotic stress-induced inactivation of mTORC1. Sci Rep. (2015) 5:13828. doi: 10.1038/srep13828

35. Kim E, Goraksha-Hicks P, Li L, Neufeld TP, Guan KL. Regulation of TORC1 by Rag GTPases in nutrient response. Nat Cell Biol. (2008) 10:93545. doi: $10.1038 /$ ncb 1753

36. Sancak Y, Peterson TR, Shaul YD, Lindquist RA, Thoreen CC, Bar-Peled L, et al. The Rag GTPases bind raptor and mediate amino acid signaling to mTORC1. Science. (2008) 320:1496-501. doi: 10.1126/science.1157535

37. Jewell JL, Kim YC, Russell RC, Yu FX, Park HW, Plouffe SW, et al. Metabolism. Differential regulation of mTORC1 by leucine and glutamine. Science. (2015) 347:194-8. doi: 10.1126/science.1259472

38. Sarbassov DD, Guertin DA, Ali SM, Sabatini DM. Phosphorylation and regulation of Akt/PKB by the rictor-mTOR complex. Science. (2005) 307:1098-101. doi: 10.1126/science.1106148

39. Jacinto E, Loewith R, Schmidt A, Lin S, Rüegg MA, Hall A, et al. Mammalian TOR complex 2 controls the actin cytoskeleton and is rapamycin insensitive. Nat Cell Biol. (2004) 6:1122-8. doi: 10.1038/ncb1183

40. Gan X, Wang J, Wang C, Sommer E, Kozasa T, Srinivasula S, et al. PRR5L degradation promotes mTORC2-mediated PKC- $\delta$ phosphorylation and cell migration downstream of Ga12. Nat Cell Biol. (2012) 14:68696. doi: $10.1038 /$ ncb 2507

41. Li X, Gao T. mTORC2 phosphorylates protein kinase Cל to regulate its stability and activity. EMBO Rep. (2014) 15:1918. doi: 10.1002/embr.201338119

42. Liu P, Gan W, Chin YR, Ogura K, Guo J, Zhang J, et al. PtdIns(3,4,5)P3dependent activation of the mTORC2 kinase complex. Cancer Discov. (2015) 5:1194-209. doi: 10.1158/2159-8290.CD-15-0460 
43. Yu Y, Yoon SO, Poulogiannis G, Yang Q, Ma XM, Villen J, et al. Phosphoproteomic analysis identifies Grb10 as an mTORC1 substrate that negatively regulates insulin signaling. Science. (2011) 332:13226. doi: 10.1126/science.1199484

44. Hirshfield AN. Development of follicles in the mammalian ovary. Int Rev Cytol. (1991) 124:43-101. doi: 10.1016/S0074-7696(08)61524-7

45. Kanatsu-Shinohara M, Schultz RM, Kopf GS. Acquisition of meiotic competence in mouse oocytes: absolute amounts of p34(cdc2), cyclin B1, cdc25C, and weel in meiotically incompetent and competent oocytes. Biol Reprod. (2000) 63:1610-6. doi: 10.1095/biolreprod63.6.1610

46. McLay DW, Carroll J, Clarke HJ. The ability to develop an activity that transfers histones onto sperm chromatin is acquired with meiotic competence during oocyte growth. Dev Biol. (2002) 241:195-206. doi: 10.1006/dbio.2001.0499

47. Albertini DF, Combelles CM, Benecchi E, Carabatsos MJ. Cellular basis for paracrine regulation of ovarian follicle development. Reproduction. (2001) 121:647-53. doi: 10.1530/rep.0.1210647

48. Baarends WM, Uilenbroek JT, Kramer P, Hoogerbrugge JW, van Leeuwen EC, Themmen AP, et al. Anti-mullerian hormone and antimullerian hormone type II receptor messenger ribonucleic acid expression in rat ovaries during postnatal development, the estrous cycle, and gonadotropin-induced follicle growth. Endocrinology. (1995) 136:495162. doi: 10.1210/endo.136.11.7588229

49. Tanaka Y, Park JH, Tanwar PS, Kaneko-Tarui T, Mittal S, Lee HJ, et al. Deletion of tuberous sclerosis 1 in somatic cells of the murine reproductive tract causes female infertility. Endocrinology. (2012) 153:40416. doi: 10.1210/en.2011-1191

50. Fan HY, Liu Z, Cahill N, Richards JS. Targeted disruption of Pten in ovarian granulosa cells enhances ovulation and extends the life span of luteal cells. Mol Endocrinol. (2008) 22:2128-40. doi: 10.1210/me.2008-0095

51. Adhikari D, Flohr G, Gorre N, Shen Y, Yang H, Lundin E, et al. Disruption of Tsc2 in oocytes leads to overactivation of the entire pool of primordial follicles. Mol Hum Reprod. (2009) 15:765-70. doi: 10.1093/molehr/gap092

52. Adhikari D, Zheng W, Shen Y, Gorre N, Hamalainen T, Cooney $\mathrm{AJ}$, et al. Tsc/mTORC1 signaling in oocytes governs the quiescence and activation of primordial follicles. Hum Mol Genet. (2010) 19:397410. doi: $10.1093 / \mathrm{hmg} / \mathrm{ddp} 483$

53. Yang Q, Guan KL. Expanding mTOR signaling. Cell Res. (2007) 17:66681. doi: $10.1038 / \mathrm{cr} .2007 .64$

54. Wang ZP, Mu XY, Guo M, Wang YJ, Teng Z, Mao GP, et al. Transforming growth factor-beta signaling participates in the maintenance of the primordial follicle pool in the mouse ovary. J Biol Chem. (2014) 289:8299311. doi: 10.1074/jbc.M113.532952

55. Lu X, Guo S, Cheng Y, Kim JH, Feng Y, Feng Y. Stimulation of ovarian follicle growth after AMPK inhibition. Reproduction. (2017) 153:68394. doi: 10.1530/REP-16-0577

56. Jiang ZZ, Hu MW, Ma XS, Schatten H, Fan HY, Wang ZB, et al. LKB1 acts as a critical gatekeeper of ovarian primordial follicle pool. Oncotarget. (2016) 7:5738-53. doi: 10.18632/oncotarget.6792

57. Gorre N, Adhikari D, Lindkvist R, Brannstrom M, Liu K, Shen Y. mTORC1 Signaling in oocytes is dispensable for the survival of primordial follicles and for female fertility. PLoS One. (2014) 9:e110491. doi: 10.1371/journal.pone.0110491

58. Zhang H, Liu K. Cellular and molecular regulation of the activation of mammalian primordial follicles: somatic cells initiate follicle activation in adulthood. Hum Reprod Update. (2015) 21:779-86. doi: 10.1093/humupd/dmv037

59. Zhang H, Risal S, Gorre N, Busayavalasa K, Li X, Shen $\mathrm{Y}$, et al. Somatic cells initiate primordial follicle activation and govern the development of dormant oocytes in mice. Curr Biol. (2014) 24:25018. doi: 10.1016/j.cub.2014.09.023

60. Zhao Y, Zhang Y, Li J, Zheng N, Xu X, Yang J, et al. MAPK3/1 participates in the activation of primordial follicles through mTORC1-KITL signaling. $J$ Cell Physiol. (2018) 233:226-37. doi: 10.1002/jcp.25868

61. Chen J, Torcia S, Xie F, Lin CJ, Cakmak H, Franciosi F, et al. Somatic cells regulate maternal mRNA translation and developmental competence of mouse oocytes. Nat Cell Biol. (2013) 15:1415-23. doi: 10.1038/ncb2873
62. McGinnis LK, Limback SD, Albertini DF. Signaling modalities during oogenesis in mammals. Curr Topics Dev Biol. (2013) 102:227-42. doi: 10.1016/B978-0-12-416024-8.00008-8

63. Abel MH, Wootton AN, Wilkins V, Huhtaniemi I, Knight PG, Charlton HM. The effect of a null mutation in the follicle-stimulating hormone receptor gene on mouse reproduction. Endocrinology. (2000) 141:1795803. doi: 10.1210/en.141.5.1795

64. Alam H, Maizels ET, Park Y, Ghaey S, Feiger ZJ, Chandel NS, et al. Follicle-stimulating hormone activation of hypoxia-inducible factor-1 by the phosphatidylinositol 3-kinase/AKT/Ras homolog enriched in brain (Rheb)/mammalian target of rapamycin (mTOR) pathway is necessary for induction of select protein markers of follicular differentiation. J Biol Chem. (2004) 279:19431-40. doi: 10.1074/jbc.M401235200

65. Alam H, Weck J, Maizels E, Park Y, Lee EJ, Ashcroft M, et al. Role of the phosphatidylinositol-3-kinase and extracellular regulated kinase pathways in the induction of hypoxia-inducible factor (HIF)-1 activity and the HIF1 target vascular endothelial growth factor in ovarian granulosa cells in response to follicle-stimulating hormone. Endocrinology. (2009) 150:91528. doi: 10.1210/en.2008-0850

66. Huang L, Wang ZB, Jiang ZZ, Hu MW, Lin F, Zhang QH, et al. Specific disruption of Tscl in ovarian granulosa cells promotes ovulation and causes progressive accumulation of corpora lutea. PLoS ONE. (2013) 8:e54052. doi: 10.1371/journal.pone.0054052

67. Schuh M, Ellenberg J. Self-organization of MTOCs replaces centrosome function during acentrosomal spindle assembly in live mouse oocytes. Cell. (2007) 130:484-98. doi: 10.1016/j.cell.2007.06.025

68. Kusch J, Liakopoulos D, Barral Y. Spindle asymmetry: a compass for the cell. Trends Cell Biol. (2003) 13:562-9. doi: 10.1016/j.tcb.2003.09.008

69. Kogasaka Y, Hoshino Y, Hiradate Y, Tanemura K, Sato E. Distribution and association of mTOR with its cofactors, raptor and rictor, in cumulus cells and oocytes during meiotic maturation in mice. Mol Reprod Dev. (2013) 80:334-48. doi: $10.1002 / \mathrm{mrd} .22166$

70. Ma XM, Blenis J. Molecular mechanisms of mTOR-mediated translational control. Nat Rev Mol Cell Biol. (2009) 10:307-18. doi: 10.1038/nrm2672

71. Bandyopadhyay A, Bandyopadhyay J, Chung J, Choi HS, Kwon $\mathrm{HB}$. Inhibition of S6 kinase by rapamycin blocks maturation of Rana dybowskii oocytes. Gen Comp Endocrinol. (1999) 113:230-9. doi: 10.1006/gcen.1998.7199

72. Morley SJ, Pain VM. Hormone-induced meiotic maturation in Xenopus oocytes occurs independently of p70s6k activation and is associated with enhanced initiation factor (eIF)-4F phosphorylation and complex formation. J Cell Sci. (1995) 108(Pt 4):1751-60.

73. Erikson E, Maller JL. In vivo phosphorylation and activation of ribosomal protein S6 kinases during Xenopus oocyte maturation. J Biol Chem. (1989) 264:13711-7.

74. Keiper BD, Rhoads RE. Cap-independent translation initiation in Xenopus oocytes. Nucleic Acids Res. (1997) 25:395-402. doi: 10.1093/nar/25.2.395

75. Siemer C, Smiljakovic T, Bhojwani M, Leiding C, Kanitz W, et al. Analysis of mRNA associated factors during bovine oocyte maturation and early embryonic development. Mol Reprod Dev. (2009) 76:120819. doi: $10.1002 / \mathrm{mrd} .21096$

76. Ellederova Z, Kovarova H, Melo-Sterza F, Livingstone M, Tomek W, Kubelka M. Suppression of translation during in vitro maturation of pig oocytes despite enhanced formation of cap-binding protein complex eIF4F and 4E-BP1 hyperphosphorylation. Mol Reprod Dev. (2006) 73:6876. doi: $10.1002 / \mathrm{mrd} .20368$

77. Romasko EJ, Amarnath D, Midic U, Latham KE. Association of maternal mRNA and phosphorylated EIF4EBP1 variants with the spindle in mouse oocytes: localized translational control supporting female meiosis in mammals. Genetics. (2013) 195:349-58. doi: 10.1534/genetics.113.154005

78. Susor A, Jansova D, Cerna R, Danylevska A, Anger M, Toralova $\mathrm{T}$, et al. Temporal and spatial regulation of translation in the mammalian oocyte via the mTOR-eIF4F pathway. Nat Commun. (2015) 6:6078. doi: 10.1038/ncomms7078

79. Shah OJ, Ghosh S, Hunter T. Mitotic regulation of ribosomal S6 kinase 1 involves Ser/Thr, Pro phosphorylation of consensus and non-consensus sites by Cdc2. J Biol Chem. (2003) 278:16433-42. doi: 10.1074/jbc.M300435200 
80. Merrick WC. Cap-dependent and cap-independent translation in eukaryotic systems. Gene. (2004) 332:1-11. doi: 10.1016/S0378-1119(04)00142-8

81. Uraji J, Scheffler K, Schuh M. Functions of actin in mouse oocytes at a glance. J Cell Sci. (2018) 131:jcs218099. doi: 10.1242/jcs.218099

82. Yi K, Li R. Actin cytoskeleton in cell polarity and asymmetric division during mouse oocyte maturation. Cytoskeleton. (2012) 69:727-37. doi: 10.1002/cm.21048

83. Lee SE, Sun SC, Choi HY, Uhm SJ, Kim NH. mTOR is required for asymmetric division through small GTPases in mouse oocytes. Mol Reprod Dev. (2012) 79:356-66. doi: 10.1002/mrd.22035

84. Schmelzle T, Hall MN. TOR, a central controller of cell growth. Cell. (2000) 103:253-62. doi: 10.1016/S0092-8674(00)00117-3

85. Kayampilly PP, Menon KM. Follicle-stimulating hormone increases tuberin phosphorylation and mammalian target of rapamycin signaling through an extracellular signal-regulated kinase-dependent pathway in rat granulosa cells. Endocrinology. (2007) 148:3950-7. doi: 10.1210/en.2007-0202

86. Sherr CJ, Roberts JM. Inhibitors of mammalian G1 cyclin-dependent kinases. Genes Dev. (1995) 9:1149-63. doi: 10.1101/gad.9.10.1149

87. Yaba A, Bianchi V, Borini A, Johnson J. A putative mitotic checkpoint dependent on mTOR function controls cell proliferation and survival in ovarian granulosa cells. Reprod Sci. (2008) 15:128-38. doi: 10.1177/1933719107312037

88. Yu J, Yaba A, Kasiman C, Thomson T, Johnson J. mTOR controls ovarian follicle growth by regulating granulosa cell proliferation. PLoS ONE. (2011) 6:e21415. doi: 10.1371/journal.pone.0021415

89. Palaniappan M, Menon KM. Human chorionic gonadotropin stimulates theca-interstitial cell proliferation and cell cycle regulatory proteins by a cAMP-dependent activation of AKT/mTORC1 signaling pathway. Mol Endocrinol. (2010) 24:1782-93. doi: 10.1210/me.2010-0044

90. Palaniappan M, Menon B, Menon KM. Stimulatory effect of insulin on theca-interstitial cell proliferation and cell cycle regulatory proteins through MTORC1 dependent pathway. Mol Cell Endocrinol. (2013) 366:819. doi: 10.1016/j.mce.2012.12.004

91. Fukuda S, Orisaka M, Tajima K, Hattori K, Kotsuji F. Luteinizing hormone-induced Akt phosphorylation and androgen production are modulated by MAP Kinase in bovine theca cells. J Ovar Res. (2009) 2:17. doi: 10.1186/1757-2215-2-17

92. Moravek MB, Shang M, Menon B, Menon K. HCG-mediated activation of mTORC1 signaling plays a crucial role in steroidogenesis in human granulosa lutein cells. Endocrine. (2016) 54:217-24. doi: 10.1007/s12020-016-1065-8

93. Hou X, Arvisais EW, Davis JS. Luteinizing hormone stimulates mammalian target of rapamycin signaling in bovine luteal cells via pathways independent of AKT and mitogen-activated protein kinase: modulation of glycogen synthase kinase 3 and AMP-activated protein kinase. Endocrinology. (2010) 151:2846-57. doi: 10.1210/en.2009-1032

94. Choi J, Jo M, Lee E, Choi D. The role of autophagy in corpus luteum regression in the rat. Biol Reprod. (2011) 85:465-72. doi: 10.1095/biolreprod.111.091314

95. Arvisais EW, Romanelli A, Hou X, Davis JS. AKT-independent phosphorylation of TSC2 and activation of mTOR and ribosomal protein S6 kinase signaling by prostaglandin F2alpha. J Biol Chem. (2006) 281:26904-13. doi: 10.1074/jbc.M605371200

96. Sugimoto Y, Yamasaki A, Segi E, Tsuboi K, Aze Y, Nishimura T, et al. Failure of parturition in mice lacking the prostaglandin F receptor. Science. (1997) 277:681-3. doi: 10.1126 /science. 277.5326 .681

97. Choi J, Jo M, Lee E, Choi D. ERK1/2 is involved in luteal cell autophagy regulation during corpus luteum regression via an mTOR-independent pathway. Mol Hum Reprod. (2014) 20:972-80. doi: 10.1093/molehr/ gau061

98. Cota D, Proulx K, Smith KA, Kozma SC, Thomas G, Woods SC, et al. Hypothalamic mTOR signaling regulates food intake. Science. (2006) 312:927-30. doi: 10.1126/science. 1124147

99. Pinilla L, Aguilar E, Dieguez C, Millar RP, Tena-Sempere M. Kisspeptins and reproduction: physiological roles and regulatory mechanisms. Physiol Rev. (2012) 92:1235-316. doi: 10.1152/physrev.00037.2010

100. Quennell JH, Howell CS, Roa J, Augustine RA, Grattan DR, Anderson GM. Leptin deficiency and diet-induced obesity reduce hypothalamic kisspeptin expression in mice. Endocrinology. (2011) 152:1541-50. doi: 10.1210/en.2010-1100

101. López M, Nogueiras R, Tena-Sempere M, Diéguez C. Hypothalamic AMPK: a canonical regulator of whole-body energy balance. Nat Rev Endocrinol. (2016) 12:421-32. doi: 10.1038/nrendo.2016.67

102. Roa J, Barroso A, Ruiz-Pino F, Vazquez MJ, Seoane-Collazo P, MartinezSanchez N, et al. Metabolic regulation of female puberty via hypothalamic AMPK-kisspeptin signaling. Proc Natl Acad Sci USA. (2018) 115:E1075867. doi: 10.1073/pnas.1802053115

103. West J, Sparagana S, Franz DN, Krueger DA, Bissler JJ, Berkowitz N, et al. Pooled analysis of menstrual irregularities from three major clinical studies evaluating everolimus for the treatment of tuberous sclerosis complex. PLoS ONE. (2017) 12:e0186235. doi: 10.1371/journal.pone.0186235

104. Zhang Y, Bokov A, Gelfond J, Soto V, Ikeno Y, Hubbard G, et al. Rapamycin extends life and health in C57BL/6 mice. J Gerontol Series A Biol Sci Med Sci. (2014) 69:119-30. doi: 10.1093/gerona/glt056

105. Franz DN, Leonard J, Tudor C, Chuck G, Care M, Sethuraman G, et al. Rapamycin causes regression of astrocytomas in tuberous sclerosis complex. Ann Neurol. (2006) 59:490-8. doi: 10.1002/ana.20784

106. Halloran J, Hussong SA, Burbank R, Podlutskaya N, Fischer KE, Sloane LB, et al. Chronic inhibition of mammalian target of rapamycin by rapamycin modulates cognitive and non-cognitive components of behavior throughout lifespan in mice. Neuroscience. (2012) 223:10213. doi: 10.1016/j.neuroscience.2012.06.054

107. Majumder S, Caccamo A, Medina DX, Benavides AD, Javors MA, Kraig $\mathrm{E}$, et al. Lifelong rapamycin administration ameliorates age-dependent cognitive deficits by reducing IL- $1 \beta$ and enhancing NMDA signaling. Aging Cell. (2012) 11:326-35. doi: 10.1111/j.1474-9726.2011.00791.x

108. Dou X, Sun Y, Li J, Zhang J, Hao D, Liu W, et al. Short-term rapamycin treatment increases ovarian lifespan in young and middleaged female mice. Aging Cell. (2017) 16:825-36. doi: 10.1111/acel. 12617

109. Alfadhli E, Koh A, Albaker W, Bhargava R, Ackerman T, McDonald $\mathrm{C}$, et al. High prevalence of ovarian cysts in premenopausal women receiving sirolimus and tacrolimus after clinical islet transplantation. Transpl Int. (2009) 22:622-5. doi: 10.1111/j.1432-2277.2009. 00839.x

110. Braun M, Young J, Reiner CS, Poster D, Krauer F, Kistler AD, et al. Low-dose oral sirolimus and the risk of menstrual-cycle disturbances and ovarian cysts: analysis of the randomized controlled SUISSE ADPKD trial. PLOS ONE. (2012) 7:e45868. doi: 10.1371/journal.pone.0045868

111. Luo LL, Xu JJ, Fu YC. Rapamycin prolongs female reproductive lifespan. Cell Cycle. (2013) 12:3353-4. doi: 10.4161/cc.26578

112. Carson DD, Bagchi I, Dey SK, Enders AC, Fazleabas AT, Lessey BA, et al. Embryo implantation. Dev Biol. (2000) 223:217-37. doi: 10.1006/dbio.2000.9767

113. Choi J, Jo M, Lee E, Kim HJ, Choi D. Differential induction of autophagy by mTOR is associated with abnormal apoptosis in ovarian endometriotic cysts. Mol Hum Reprod. (2014) 20:309-17. doi: 10.1093/molehr/gat091

114. Choi J, Jo M, Lee E, Oh YK, Choi D. The role of autophagy in human endometrium. Biol Reprod. (2012) 86:70. doi: 10.1095/biolreprod.111.096206

115. Gellersen B, Brosens JJ. Cyclic decidualization of the human endometrium in reproductive health and failure. Endocr Rev. (2014) 35:851-905. doi: 10.1210/er.2014-1045

116. Zhang X, Fu L-J, Liu X-Q, Hu Z-Y, Jiang Y, Gao R-F, et al. nm23 regulates decidualization through the PI3K-Akt-mTOR signaling pathways in mice and humans. Hum Reprod. (2016) 31:2339-51. doi: 10.1093/humrep/dew191

117. Tabibzadeh S, Babaknia A. The signals and molecular pathways involved in implantation, a symbiotic interaction between blastocyst and endometrium involving adhesion and tissue invasion. Hum Reprod. (1995) 10:1579602. doi: 10.1093/HUMREP/10.6.1579

118. Craciunas L, Gallos I, Chu J, Bourne T, Quenby S, Brosens JJ, et al. Conventional and modern markers of endometrial receptivity: a systematic review and meta-analysis. Hum Reprod Update. (2019) 25:20223. doi: 10.1093/humupd/dmy044

119. Hesam Shariati MB, Seghinsara AM, Shokrzadeh N, Niknafs B. The effect of fludrocortisone on the uterine receptivity partially mediated by ERK1/2mTOR pathway. J Cell Physiol. (2019) 234:20098-110. doi: 10.1002/jcp.28609 
120. Chen X, He J, Ding Y, Zeng L, Gao R, Cheng S, et al. The role of MTOR in mouse uterus during embryo implantation. Reproduction. (2009) 138:3516. doi: 10.1530/REP-09-0090

121. Zeng $\mathrm{X}$, Mao $\mathrm{X}$, Huang $\mathrm{Z}$, Wang $\mathrm{F}, \mathrm{Wu} \mathrm{G}$, Qiao S. Arginine enhances embryo implantation in rats through $\mathrm{PI} 3 \mathrm{~K} / \mathrm{PKB} / \mathrm{mTOR} / \mathrm{NO}$ signaling pathway during early pregnancy. Reproduction. (2013) 145:17. doi: 10.1530/REP-12-0254

122. Wollenhaupt K, Brussow KP, Albrecht D, Tomek W. The Akt/mTor signaling cascade is modified during placentation in the porcine uterine tissue. Reprod Biol. (2013) 13:184-94. doi: 10.1016/j.repbio.2013.06.001

123. Wollenhaupt K, Brussow KP, Albrecht D, Tomek W. The eIF4E repressor protein $4 \mathrm{E}-\mathrm{BP} 2$ is merely truncated, despite $4 \mathrm{E}-\mathrm{BP} 1$ degradation in the porcine uterine tissue during implantation. Mol Reprod Dev. (2012) 79:76776. doi: $10.1002 / \mathrm{mrd} .22108$

124. Montagne J, Stewart MJ, Stocker H, Hafen E, Kozma SC, Thomas G. Drosophila S6 kinase: a regulator of cell size. Science. (1999) 285:21269. doi: $10.1126 /$ science.285.5436.2126

125. Oldham S, Montagne J, Radimerski T, Thomas G, Hafen E. Genetic and biochemical characterization of dTOR, the Drosophila homolog of the target of rapamycin. Genes Dev. (2000) 14:2689-94. doi: 10.1101/gad.845700

126. Hentges KE, Sirry B, Gingeras AC, Sarbassov D, Sonenberg N, Sabatini $\mathrm{D}$, et al. FRAP/mTOR is required for proliferation and patterning during embryonic development in the mouse. Proc Natl Acad Sci USA. (2001) 98:13796-801. doi: 10.1073/pnas.241184198

127. Hentges K, Thompson K, Peterson A. The flat-top gene is required for the expansion and regionalization of the telencephalic primordium. Development. (1999) 126:1601-9.

128. Pende M, Um SH, Mieulet V, Sticker M, Goss VL, Mestan J, et al. S6K1(/-)/S6K2(-/-) mice exhibit perinatal lethality and rapamycin-sensitive 5'terminal oligopyrimidine mRNA translation and reveal a mitogen-activated protein kinase-dependent S6 kinase pathway. Mol Cell Biol. (2004) 24:311224. doi: 10.1128/MCB.24.8.3112-3124.2004

129. Fenelon JC, Banerjee A, Murphy BD. Embryonic diapause: development on hold. Development. (2014) 58:163-74. doi: 10.1387/ijdb.140074bm

130. Renfree MB, Fenelon JC. The enigma of embryonic diapause. (2017) 144:3199-210. doi: 10.1242/dev.148213

131. Bulut-Karslioglu A, Biechele S, Jin H, Macrae TA, Hejna M, Gertsenstein M, et al. Inhibition of mTOR induces a paused pluripotent state. Nature. (2016) 540:119-23. doi: 10.1038/nature20578

132. Kojima Y, Tam OH, Tam PP. Timing of developmental events in the early mouse embryo. Sem Cell Dev Biol. (2014) 34:65-75. doi: 10.1016/j.semcdb.2014.06.010

133. Smith AG, Heath JK, Donaldson DD, Wong GG, Moreau J, Stahl M, et al. Inhibition of pluripotential embryonic stem cell differentiation by purified polypeptides. Nature. (1988) 336:688-90. doi: 10.1038/ 336688a0

134. Cherepkova MY, Sineva GS, Pospelov VA. Leukemia inhibitory factor (LIF) withdrawal activates mTOR signaling pathway in mouse embryonic stem cells through the MEK/ERK/TSC2 pathway. Cell Death Dis. (2016) 7:e2050. doi: 10.1038/cddis.2015.387

135. Gomez-Salinero JM, Lopez-Olaneta MM, Ortiz-Sanchez P, LarrasaAlonso J, Gatto A, Felkin LE, et al. The calcineurin variant CnAbeta1 controls mouse embryonic stem cell differentiation by directing mTORC2 membrane localization and activation. Cell Chem Biol. (2016) 23:137282. doi: 10.1016/j.chembiol.2016.09.010

136. Nazareth EJP, Rahman N, Yin T, Zandstra PW. A multi-lineage screen reveals mTORC1 inhibition enhances human pluripotent stem cell mesendoderm and blood progenitor production. Stem Cell Rep. (2016) 6:679-91. doi: 10.1016/j.stemcr.2016.04.003

137. Jung JH, Kang KW, Kim J, Hong SC, Park Y, Kim BS. CXCR2 inhibition in human pluripotent stem cells induces predominant differentiation to mesoderm and endoderm through repression of mTOR, beta-Catenin, and hTERT activities. Stem Cells Dev. (2016) 25:1006-19. doi: 10.1089/scd.2015.0395

138. Meng D, Frank AR, Jewell JL. mTOR signaling in stem and progenitor cells. Development. (2018) 145:dev152595. doi: 10.1242/dev. 152595
139. Goldman KN, Chenette D, Arju R, Duncan FE, Keefe DL, Grifo JA, et al. mTORC1/2 inhibition preserves ovarian function and fertility during genotoxic chemotherapy. Proc Natl Acad Sci USA. (2017) 114:318691. doi: 10.1073/pnas.1617233114

140. Meirow D, Biederman H, Anderson RA, Wallace WH. Toxicity of chemotherapy and radiation on female reproduction. Clin Obst Gynecol. (2010) 53:727-39. doi: 10.1097/GRF.0b013e3181f96b54

141. Kalich-Philosoph L, Roness H, Carmely A, Fishel-Bartal M, Ligumsky H, Paglin S, et al. Cyclophosphamide triggers follicle activation and "burnout"; AS101 prevents follicle loss and preserves fertility. Sci Transl Med. (2013) 5:185ra62. doi: 10.1126/scitranslmed.3005402

142. Tanaka Y, Kimura F, Zheng L, Kaku S, Takebayashi A, Kasahara K, et al. Protective effect of a mechanistic target of rapamycin inhibitor on an in vivo model ofcisplatin-induced ovarian gonadotoxicity. Exp Anim. (2018) 67:493-500. doi: 10.1538/expanim.18-0042

143. Zhou L, Xie Y, Li S, Liang Y, Qiu Q, Lin H, et al. Rapamycin prevents cyclophosphamide-induced over-activation of primordial follicle pool through PI3K/Akt/mTOR signaling pathway in vivo. (2017) 10:56. doi: 10.1186/s13048-017-0350-3

144. Kallen A, Polotsky AJ, Johnson J. Untapped reserves: controlling primordial follicle growth activation. Trends Mol Med. (2018) 24:31931. doi: 10.1016/j.molmed.2018.01.008

145. Sun X, Su Y, He Y, Zhang J, Liu W, Zhang H, et al. New strategy for in vitro activation of primordial follicles with mTOR and PI3K stimulators. Cell Cycle. (2015) 14:721-31. doi: 10.1080/15384101.2014.995496

146. Cheng Y, Kim J, Li XX, Hsueh AJ. Promotion of ovarian follicle growth following mTOR activation: synergistic effects of AKT stimulators. PLoS ONE. (2015) 10:e0117769. doi: 10.1371/journal.pone.0117769

147. Teede HJ, Misso ML, Costello MF, Dokras A, Laven J, Moran L, et al. Recommendations from the international evidence-based guideline for the assessment and management of polycystic ovary syndrome. Fertil Steril. (2018) 110:364-79. doi: 10.1016/j.fertnstert.2018.05.004

148. Apridonidze T, Essah PA, Iuorno MJ, Nestler JE. Prevalence and characteristics of the metabolic syndrome in women with polycystic ovary syndrome. J Clin Endocrinol Metab. (2005) 90:1929-35. doi: 10.1210/jc.2004-1045

149. Yaba A, Demir N. The mechanism of mTOR (mammalian target of rapamycin) in a mouse model of polycystic ovary syndrome (PCOS). J Ovar Res. (2012) 5:38. doi: 10.1186/1757-2215-5-38

150. Song WJ, Shi X, Zhang J, Chen L, Fu SX, Ding YL. Akt-mTOR signaling mediates abnormalities in the proliferation and apoptosis of ovarian granulosa cells in patients with polycystic ovary syndrome. Gynecol Obstet Invest. (2018) 83:124-32. doi: 10.1159/000464351

151. Fang Y, Westbrook R, Hill C, Boparai RK, Arum O, Spong A, et al. Duration of rapamycin treatment has differential effects on metabolism in mice. Cell Metab. (2013) 17:456-62. doi: 10.1016/j.cmet.2013.02.008

152. Fox C, Morin S, Jeong JW, Scott RT Jr, Lessey BA. Local and systemic factors and implantation: what is the evidence? Fertil Steril. (2016) 105:87384. doi: 10.1016/j.fertnstert.2016.02.018

153. Park JS, Lee JH, Kim M, Chang HJ, Hwang KJ, Chang KH. Endometrium from women with endometriosis shows increased proliferation activity. Fertil Steril. (2009) 92:1246-9. doi: 10.1016/j.fertnstert.2009.04.025

154. Guo J, Gao J, Yu X, Luo H, Xiong X, Huang O. Expression of DJ-1 and mTOR in eutopic and ectopic endometria of patients with endometriosis and adenomyosis. Gynecol Obstet Invest. (2015) 79:195200. doi: 10.1159/000365569

155. Yagyu T, Tsuji Y, Haruta S, Kitanaka T, Yamada Y, Kawaguchi $\mathrm{R}$, et al. Activation of mammalian target of rapamycin in postmenopausal ovarian endometriosis. Int J Gynecol Cancer. (2006) 16:1545-51. doi: 10.1111/j.1525-1438.2006.00625.x

156. Honda H, Barrueto FF, Gogusev J, Im DD, Morin PJ. Serial analysis of gene expression reveals differential expression between endometriosis and normal endometrium. Possible roles for AXL and SHC1 in the pathogenesis of endometriosis. Reprod Biol Endocrinol. (2008) 6:59. doi: 10.1186/1477-7827-6-59

157. Kacan T, Yildiz C, Baloglu Kacan S, Seker M, Ozer H, Cetin A. Everolimus as an mTOR inhibitor suppresses endometriotic implants: 
an experimental rat study. Geburtshilfe Frauenheilkund. (2017) 77:6672. doi: $10.1055 / \mathrm{s}-0042-115566$

158. Leconte M, Nicco C, Ngo C, Chereau C, Chouzenoux S, Marut W, et al. The mTOR/AKT inhibitor temsirolimus prevents deep infiltrating endometriosis in mice. Am J Pathol. (2011) 179:880-9. doi: 10.1016/j.ajpath.2011.04.020

159. Choi J, Jo M, Lee E, Lee DY, Choi D. Dienogest enhances autophagy induction in endometriotic cells by impairing activation of AKT, ERK1/2, and mTOR. Fertil Steril. (2015) 104:655-64 e1. doi: 10.1016/j.fertnstert.2015.05.020

160. Lessey BA, Kim JJ. Endometrial receptivity in the eutopic endometrium of women with endometriosis: it is affected, and let me show you why. Fertil Steril. (2017) 108:19-27. doi: 10.1016/j.fertnstert.2017.05.031

161. Yin X, Pavone ME, Lu Z, Wei J, Kim JJ. Increased activation of the PI3K/AKT pathway compromises decidualization of stromal cells from endometriosis. $J$ Clin Endocrinol Metab. (2012) 97:E35-43. doi: 10.1210/jc.2011-1527

162. McKinnon BD, Kocbek V, Nirgianakis K, Bersinger NA, Mueller MD. Kinase signalling pathways in endometriosis: potential targets for non-hormonal therapeutics. Hum Reprod Update. (2016) 22:382-403. doi: 10.1093/humupd/ dmv060

163. Barra F, Ferro Desideri L, Ferrero S. Inhibition of PI3K/AKT/mTOR pathway for the treatment of endometriosis. Br J Pharmacol. (2018) 175:362627. doi: 10.1111/bph.14391

Conflict of Interest: The authors declare that the research was conducted in the absence of any commercial or financial relationships that could be construed as a potential conflict of interest.

Copyright (C) 2019 Guo and Yu. This is an open-access article distributed under the terms of the Creative Commons Attribution License (CC BY). The use, distribution or reproduction in other forums is permitted, provided the original author(s) and the copyright owner(s) are credited and that the original publication in this journal is cited, in accordance with accepted academic practice. No use, distribution or reproduction is permitted which does not comply with these terms. 